\title{
Power, Space, and Place in Early ChildhoOd EducATion
}

\author{
CORY JoBB
}

Abstract. This paper addresses early childhood educators' perceptions on how power relations are shaped by interactions between themselves, children, and the material environment. In a qualitative three-phase case study I explored educators' perceptions on how power relations are enacted within one preschool classroom in Southern Ontario, and how power relations are affected when educators conceptualize the environment through the perspective of space and place. Drawing on reconceptualist theory in early childhood education, children's spatialities, and Michel Foucault's work on power in society, I suggest that power circulates between bodies and spatialities, in the complex interactions between individuals and the physical spaces they encounter. The findings suggest that while early childhood educators may understand intuitively the demarcation between space and place, external constraints - real or perceived - are barriers to change. I argue that shifting philosophical and pedagogical stances in early childhood education have resulted in two binarized positions, where philosophy and pedagogy are frequently understood as either child-centred, or teacher-directed orientations and that troubling the binary by thinking with place can help refigure power relations between educators and young children. The conceptual distinction between thinking of early childhood classrooms as space or place is significant and I argue that viewing the environment as place is one possible way educators can reconceptualize traditionally hierarchical and binarized power dynamics between themselves and young children.

Keywords: Space and place; Power relations; Early childhood education; Reconceptualist theory; Foucault 


\section{INTRODUCTION}

D)ower relations are enacted within early childhood settings through both interactions between individuals, and interactions between individuals and the material environment (Vuorisalo, Rutanen \& Raittila 2015). Power relations are complicated by what Lenz Taguchi (2010) characterizes as the theory/practice divide in early childhood studies that manifest themselves in pervading binaried ways of thinking and doing early childhood education. Significant conceptual and pedagogical shifts within the field continue to reinscribe either/or thinking about early childhood practice. For example, in present-day discourses of early childhood education, it is common to find educators invoking the stance of child-centred pedagogy (or derivatives such as emergent curriculum or inquiry-based learning) that position children as active and competent agents (Wood 2014). The discourse represents shifting perspectives regarding who has power and knowledge within the early childhood classroom but has resulted in pedagogical orientations that are often categorized within a binarized view of child-centred pedagogies as situated in direct opposition to teacher-directed pedagogies. Teacher-directed pedagogies can be traditionally conceived of as top-down, authoritative power structures, whereas child-centred pedagogies are viewed as more emergent and responsive to the interests of young children in ways that resist standardization and predictable outcomes (Nxumalo, Vintimilla \& Nelson 2018). While the divide has manifested itself across early childhood environments as a philosophical and pedagogical shift away from teacher-directed pedagogy toward child-centred orientations, there remain questions as to where power is located and how shifting orientations may continue to reinscribe hierarchical notions of power. The possibilities have ontological and epistemological implications for both pedagogy and philosophy in early childhood settings.

Concurrently, place-based education is a still-emerging philosophical and pedagogical approach to early childhood education, but one that Duhn (2012) argues is often assumed, rather than interrogated, in theory and practice. Emerging from human geography, early childhood discourses surrounding space and place posit children's relations with their everyday geographies as always-already entangled (Nairn \& Kraftl 2016). Situating early childhood environments as both space and place is intentional and, in this paper, I demarcate space and place as necessarily separate entities as a means of working through the binaries to move toward a more situated and fluid thinking of power relations with/in children's spatialities. Although the importance of the physical space - both within and outside of traditional learning environments - 
of early childhood settings has been extensively studied (Christensen 2008; Gandini 1998; Torquati \& Ernst 2013) and there is a growing body of research into place-attuned education and pedagogies (Duhn 2012; Pacini-Ketchabaw \& Taylor, 2015; Strong-Wilson \& Ellis 2007; Taylor \& Giugni 2012), in this paper I connect notions of space and place with a Foucauldian notion of power to examine possibilities for reconceptualizing pedagogies.

Viewing the environment as space through a Foucauldian lens complicates child-centred pedagogies when the locus of control remains conceived with the individual(s), usually educators, who enact their power to direct, shift, and adapt the physical space. An understanding of power as a unidirectional flow from educators to children fails to account for the ways in which young children are attuned to and shape the spaces in which they exist. Thus, there is a need to contest the binarized ways of conceiving power as unilateral in early childhood spaces. To the contrary, re-thinking the material and discursive encounters with/in early childhood environments - when situated as place - denotes a sense of shared power through "felt value" (Tuan 1977: 4). Space is physical, but place emphasizes an emotional connection that is produced and potentially put into conflict through socio-material-political structures, or what Doreen Massey (2005) referrs to as power-geometries. To experience place is to co-construct meaning and be co-constructed through interactions between individuals and the spatial in differing and often unequal ways (Massey 2005; Tuan 1977).

In this article I discuss the findings and implications from a threephase qualitative case study that explored the ways in which a team of early childhood educators in one preschool classroom in Southern Ontario perceive how power operates between themselves, young children, and the material environment. Following arguments from human geography, I address space and place as conceptually distinct ideas that cultivate, respectively, a distinction between the physicality of early childhood locales and the meaning imparted upon that locale by educators and young children. In doing so, I argue that power relations are more fluid than suggested by binarized child-centred or teacher-directed orientations and suggest that thinking with a place-based orientation to reconceptualize early childhood spaces as early childhood places is a meaningful demarcation to aid in repositioning the fluidity and circulation of power. I also address how rethinking hierarchical or binarized perspectives on power relations may be possible when reconceptualizing early childhood locales from spaces to places. I use a reconceptualist theoretical framework (Iannacci \& Whitty 2009; Pacini-Ketchabaw \& Pence 2005) that weaves together the work of Michel Foucault (1980), 
and theories of space and place in children's geographies (Christensen 2008; Duhn 2012; Hackett, Proctor \& Seymour 2015; Nairn \& Kraftl 2016; Tuan 1977) to interrogate early childhood educators' perceptions of the power relations between children and educators.

\section{Untangling Space and Place}

Briefly, before delving into power relations, it is first useful to make clear the distinctions between space and place. According to Harrison and Dourish (1996: 2), "Space is the structure of the world; it is the three-dimensional environment, in which objects and events occur, and in which they have relative position and direction." This description of space is sufficient for situating the physicality and locality of early childhood environments as geographical space, but further parsing of the meaning of space is necessary to establish a conceptualization of early childhood spaces as locales of power. I distinguish the early childhood environment as place - as conceptually distinct from space - not to further cement the pervading binaried ways of doing early childhood studies, but rather to advance the understanding of the environment as a place imbued with fluidity, embodied and enacted power relations, and to advance the idea of possibilities for reconceptualizing power relations in place.

Where space may be conceived as rigid and defined by the strictures of its physicality, I echo Massey (2005) in suggesting that place is mutable, fluid, and deeply situated and contextual, and so upon distinguishing space as the physicality of a locale, it is then necessary to briefly define place. Harrison and Dourish (1996: 3) argue that, "physically, a place is a space which is invested with understandings of behavioural appropriateness, cultural expectations, and so forth. We are located in 'space', but we act in 'place'. Furthermore, 'places' are spaces that are valued." Similarly, Nairn and Kraftl (2016: 5) argue: "places gain meaning - through human action, through dwelling, through emotional attachments, through events, and through memories attached to them." Massey (2005) draws from feminist and postcolonial theory to point to the ways in which unequal power relations are produced within spatialities; her framing of power in place and space is useful for contextualizing the fluidity of power in early childhood settings. Transposing these key distinctions between place and space in human geography (Cresswell 2004; Cresswell 2008; Harrison \& Dourish 1996; Massey 2005; Nairn \& Kraftl 2016; Tuan 1977) into early childhood contexts is useful for rethinking place as relational and constructed through interactions between educa- 
tors, young children, and the physical environment - where power is negotiated, refuted, and assumed.

\section{Perspectives on Power Relations in Early Childhood}

The work of Michel Foucault is central to the arguments I advance in this paper; that space and place are conceptually distinct, and that the conceptual shift from space to place in early childhood contexts may be useful for rethinking binarized, hierarchical power relations between educators and young children. Foucault (1980) sought to understand how power and knowledge circulate through society and his genealogical work on power and knowledge is a useful framework for exploring power relations within early childhood education. For example, the resounding 'laugh of Foucault' in early childhood discourse builds on de Certeau's (1986) analysis to describe how "discourse can manifest in ways contrary to that anticipated by its original exponents" (Fenech, Sumsion \& Goodfellow 2008: 45) and is observable in uneven and unstable power dynamics. Power, according to Foucault (1980), is a circulating entity that does not consolidate itself within one individual, class, or institution, and it flows amidst and between individuals, as the subject is both constituted by power and, "at the same time its vehicle" (p. 98). This point is imperative for thinking with a Foucauldian conception of power in early childhood spaces, as it suggests that despite the seeming hierarchy that exists within traditional conceptualizations of adult-child interactions, both adults and children are simultaneously experiencing and exerting power. In the current landscape of early childhood education, many educators have made efforts toward enacting a philosophical and practical shift away from teacher-directed pedagogies to disrupt traditionally conceived authoritative power structures, but questions regarding how power is enacted, and how power is experienced through interactions with the spaces and places of early childhood are of ongoing importance. Research in critical early childhood studies (see Bloch 2013; Pacini-Ketchabaw \& Pence 2005; Tesar, 2014) has emerged to address such questions, including power relations, through orientations that seek to refigure early childhood theory and practice.

Reconceptualist perspectives in early childhood education closely mirror those of continental philosophy, namely, as Critchley (2001: 64) explains, "if human experience is a contingent creation, then it can be recreated in other ways." The interactions between children and educators are enacted within socially-and-culturally-situated ontological assumptions. Historically, obedience to the authority of adults has been 
the dominant expectation of children and childhood (Raby 2014). However, reconceptualist perspectives have drawn on Foucauldian analyses of power as neither, "monolithic nor total" (Dahlberg, Moss, \& Pence 1999: 33), but rather as an entity to resist and challenge and, in doing so, contribute to a more fluid and circulating conception of power in early childhood education (MacNaughton 2005). Reconceptualist scholars have advanced new perspectives to shift the discourse toward what Pacini-Ketchabaw and Pence (2005: 6) characterize as a willingness on the part of some educators to accept a, "loss of certainty, control and predictability, openness to the presence of many voices and views, and the need to engage with those other views and explore a world of profound diversity." However, the striated nature of the ongoing theory/practice divide (Lenz Taguchi 2010) has resulted in uncertainty in classroom practice, where educators may espouse a child-centred pedagogical orientation while enacting teacher-directed pedagogies (Langford 2010). This striation between theory and practice can reproduce the inequitable power relations child-centred orientations purport to redress.

\section{Foucault, Power and Children's Spatialities}

Though Foucault did not theorize power in childhood contexts, his work has been taken up by reconceptualist scholars (Kummen 2010; MacNaughton 2005) as a means of theorizing both childhood and childhood locales as environments within which the social production of power is constituted. At times, Foucault's (1980) work expounded upon power as constituted within spatialities and geographies, and similarly, scholars have used his work to construct an understanding of power within spatial experiences (Crampton \& Elden 2007). Foucault's and other scholars' writings on power and spatialities (Agnew 2011; Crampton \& Elden 2007; Elden 2001; Philo 2010; Smith 2014) are useful for observing how power is constituted within both the physical expanse of space and the notion of place, demarcated within much of the literature on place as space imbued with discursive and material meaning.

In a 1976 interview with the French Marxist-Geography journal Hèrodote, Foucault discussed the role of space and geography in his conceptualization of power. Though initially hesitant to ascribe power to spatialities, Foucault (1980: 71) ultimately relented and acknowledged that, "the spatializing description of discursive realities gives on to the analysis of related effects of power." In other words, geography, for Foucault, becomes one component of the discourse of power, in which subjects are constituted and governed by the power in spatialities to guide 
and govern human activity. Crampton and Elden (2007) contend that though Foucault did not explicitly acknowledge the importance of geography and spatiality in his work, it was nonetheless a significant and essential component of his ontology of power. Foucault's work on the role of power within places - hospitals, prisons, institutions, and schools to name a few - indicates his positioning of power within specific locales. Scholars have acknowledged Foucault's influence on the discourse of power in places and undertake a critical reading of his work (Crampton \& Elden 2007; Elden 2001). They have characterized his analyses of power within spaces and places as particularly rigorous for an academic not intimately familiar with the field of geography, and in an interesting rhetorical turn suggest that Foucault wrote, "spatial histories" rather than "histories of space" which used "space itself as a critical tool of analysis" (Elden 2001: 118-119). They argue that because Foucault himself had an unsteady conceptualization of place, space, and power, it remains an undeveloped - but significant - aspect to his work, and thus, after his death, it has become the role of geographers and philosophers to move his work into the study of spatialities.

Elsewhere, both Philo (1992; 2010) and Agnew (2011) have taken on the task of drawing attention to the spatial histories of Foucault and argue that his analyses of power within space is significant to the field of geography and spatialities. Philo (1992; 2010), following Foucault's analytic strategies, provides an overview of the works that constitute Foucault's spatial histories and argues that from a Foucauldian perspective, "the enactment of spatial innovations across all manner of institutions" (2010: 167) are used as tools and strategies of governance and power. Agnew's (2011) analysis of the power of spatialities is contingent on interactions between space and humans. Agnew (2011) offers a conceptual shift away from most Foucauldian geographers and does not ascribe power or agency to space; instead Agnew insists that a spatial history must consider the role of human interaction with the materialspatial world.

Smith $(2012 ; 2014)$ moves a Foucauldian view of spatiality into early childhood contexts, arguing that Foucault's (1980) conceptualization of disciplinary power is crucial to understanding the embodiment and enactment of power within children's spatialities. According to Smith (2014: 123), Foucault called this embodiment the "art of distributions", and that disciplinary power is enacted within spatialities. The art of distributions refers to the ways in which individuals who govern children's movements and actions - parents and educators, for example - use space to control children's experiences. Smith (2014) also follows Gore's (1998) reading of Foucault, in which surveillance is identified as a key tool of 
power in spatialities and argues that power is enacted within space by distributing children throughout spatialities to maximize supervision, or surveillance, thereby maximizing control and disciplinary power.

\section{Children's Spatialities and Reconceptualist Work in Early Childhood Studies}

Young children learn about space through their interactions with the physicality of space: both the expanse and the possibilities of wideopen spaces, and the tangible restrictions of spatialities (Tovey 2007) - for example, a playpen during infancy. Spatial theory has contributed to understanding the multiplicity of young children's lived experiences through space and place (Hackett, Proctor, \& Seymour 2015). Hackett et al. (2015) argue that children's experiences unfold through agentic interactions with their surrounding environment. Space, in the context of childhood, according to Tovey (2007), is not limited to the notion of expanse, but also encompasses size and shape and can enable or restrict movement. Along similar lines, Satta (2015) argues that children's spaces are often conceptualized as separate, and that children's play spaces in particular are understood and positioned as spaces for children - distinct from adult spaces - but in practice are often controlled and restricted by adults positioned as "in charge" (p. 179). Kernan (2010) echoes this perspective, suggesting that the conceptual demarcation between children's spatialities and adult spatialities has contributed to children's loss of independence. Critical reconceptualist early childhood scholarship has advanced a common worlds orientation (Hamm 2015; Taylor \& Giugni 2012) to reframe space as place in order to think of children's lives and experiences as relational, situated, and entangled with/in place.

In human geography, Tuan (1977) writes of the interconnected nature of space and place, stating that neither can exist without its counterpoint. Place as a conceptual center is rich with geographical, physical, and philosophical connotations all of which are useful for understanding children's geographies (Pacini-Ketchabaw \& Taylor 2015). Agnew (2011) suggests that three defining characteristics constitute place: (1) location, or a physical space where people and materials are located, (2) locales, or the locations where social life is enacted, and (3) a sense of place, or meaning ascribed to a physical space by those who use or inhabit it. Similarly, on place, Cresswell (2008) ascribes the importance of materiality, functionality, and the attachment of meaning. In early childhood contexts, Tuan (1977) argues that children's understanding of place is developed through temporal, material, and spatial interactions with the 
world. Tuan suggests that children's identities and understandings of the world are constructed through space, in relation to those around them, similar to the arguments advanced by common worlds scholars in reconceptualist early childhood education (Hamm 2015; Pacini-Ketchabaw \& Taylor 2015; Taylor \& Giugni 2012).

There are critical implications for reconceptualizing early childhood spaces as early childhood places, and there are difficult socio-political and historical contexts to reckon with in studying childhood spaces and places. Pacini-Ketchabaw and Taylor (2015) point to the challenges of reconciling past and present notions of space and place in the context of Indigenous worldviews as contrasted with the ongoing legacy of settlercolonialism. Harrison and Hutton (2014) explore the design of space and place in educational environments and argue that a place-based approach to designing learning environments is conducive to shared power. Hognestad and Bøe (2012) developed a framework for understanding early learning environments as place, representing a methodological shift away from the traditional data collection of researcher-child practice and toward researcher-place practice. The value in this methodological shift is understanding the power of place, and the capacity of educators and children to construct shared knowledge through intra-actions (Lenz Taguchi 2010) with place. Agnew (2011) argues that knowledge is produced and reproduced in place, indicative of the power of place when imbued with meaning. Meanwhile, Duhn (2012: 104) suggests pedagogical considerations for reconceptualizing early childhood settings as place, stating that "pedagogies of places negotiate flows and create spaces where matter, desire, human and more-than-human come together to modulate the self in relation to the world." Place, Duhn (2012) argues, implies attachment for both children and educators, and the pedagogical implications require a critical reframing of power dynamics made possible through a sense of place in early childhood settings.

To be clear, there is power in conceptualizations of both space and place (Cresswell 2004; 2008; Massey 2005); however, my contention is that contesting hierarchical power relations requires reconceptualizing early childhood spaces as early childhood places, as it suggests a shared intimacy and shared meaning within the context of spatialities. Hackett et al. (2015) and Hackett (2016) observed children's movements through museums and suggest that children's meaning-making is an embodied process, enacted through agentic movements during repeated encounters with/in the space of the museum, representing a conceptual shift to place. In Hackett's research, data were collected as children moved through a museum, but research on emplacement (Christensen 2003) suggests that the findings may be replicable across children's spatialities. Children and 
educators experience place through shared movements in space where it is possible to subvert traditional power relations, but it remains unclear where power is located within the social and spatial experiences of the shared places of early childhood educators and young children.

Aligning myself with and following reconceptualist and Foucauldian perspectives that reject universalities (Bloch 2013; Foucault 1980; Pacini-Ketchabaw \& Pence 2005), or generalizable findings, this qualitative research focused on specific problems within the available literature on the theory and practice divide (see Lenz Taguchi 2010) to explore how perceptions of the environment as place and space contribute to how power relations are enacted in early childhood contexts.

\section{Methodology}

The purpose of this research was to explore how power relations are perceived and enacted in one early childhood classroom in Southern Ontario. I describe my findings from this case study (Creswell \& Poth 2017; Merriam 2009; Stake 2000) of interactions between educators and young children, as well as the broader context of the early learning environment when it is situated as place and space. The two participants - Niki and Brar - are a preschool teaching team in a large organization in Southern Ontario and were recruited using a purposive sampling procedure for participation in the study. At the time of the research Niki had been an early childhood educator for 17 years, while Brar was qualified as both a teacher and an early childhood educator and had worked in the field for two years upon completing his teaching degree and his diploma in early childhood education. Together, Brar and Niki had co-taught for less than one year. To frame the discussion of the findings, I draw from three data sources which include one semi-structured interview conducted with both participants simultaneously that lasted approximately 75 minutes; a reflective journaling exercise where both participants submitted written responses to four weekly journal prompts; and classroom observations that I gathered to examine educators' perceptions of how power operates between children and early childhood educators in one preschool classroom in Southern Ontario.

\section{Power, Space, and Place: Findings}

The role of the physical environment in how power operates between educators and young children is considerable in the perceptions and practices of Niki and Brar. During our interview, Niki indicated that she 
believes that there is a clear distinction between space and place, and her perception is their classroom is felt by the educators and children as being somewhere in between, with characteristics of both. Here, as before, I have differentiated between space and place as a way to provide clarity on the ways in which individuals' interactions with the physical environment are constituted by power relations, and how power relations may be viewed as less binary and more mutable. The findings are organized in this article under two key conceptual themes: the classroom as space, and the classroom as place. There are two important considerations to make clear before I describe the findings.

First, many of the examples throughout the three phases of data collection that I describe as examples of power are innocuous, quotidian happenings, and similar examples would likely be observable across early learning environments and contexts globally. Nonetheless, these examples represent an interaction with either an individual, or the environment that is constituted by the enactment of power and it is important to highlight that the actions of the individual(s) at the center of the interaction are altered due to the influence of other forces, including interactions with others, regulations, time, and the physical environment. To this point, Niki and Brar's interactions with the children were respectful and encouraging and it would be inaccurate to describe the power relations in their classroom as authoritarian. Niki and Brar spoke with authority at times, but never in ways that were domineering or that diminished the dignity of the children in their program. Similarly, where I have indicated that the preparation of the physical environment - moving chairs and setting out beds, for example - is an example of the educators' power in the classroom, it is not an authoritarian act: it is pragmatic. Children need chairs to sit on and beds to sleep in, but it was evidence of power in the classroom in that their arrangement appeared to be a decision made only by Brar and Niki, and those decisions influenced where and how children spent their time.

Second, there is considerable thematic overlap within the analysis and grouping of concepts in a way that creates a full picture of how power operates in Niki and Brar's classroom. In many instances, it was challenging to decide how best to group a particular instance of observed or described power. For example, when Niki and Brar explained that there are times of the day - e.g., lunch time, outdoor time, sleep time that are decided by their organization, it could be construed as both an example of power through temporality and power through regulations. In the context of how Niki and Brar described these examples, it was about how they perceived the power of their organization rather than an example of how power is enacted through time. In this and similar in- 
stances, I looked to the context of the conversation, journal entries, or the onsite observation, to determine how best to present these narratively.

\section{The classroom as space.}

There was some overlap between the findings relating to power in the classroom when conceptualized as space and the positioning and use of materials and furniture in the classroom. While Niki led circle time, for instance, Brar prepared the room for sleep time. He moved furniture out of the way to accommodate the children's beds, and he placed the beds throughout the room. I asked him who decides where the children's beds are placed, and he acknowledged that he and Niki determine their placement, and that it is determined by multiple factors, including the layout of the room and their perceptions of the personality and needs of individual children.

At times, there was conceptual overlapping within the participants' perceptions of the physical environment. Brar shared many thoughts on the classroom as either a space or a place. His perceptions on conceptualizing the classroom as either space or place related to who held power in a particular situation. In his journal, Brar wrote, "I call it a space because space is something that is particularly designed for some particular purpose and that is what our classroom and curriculums are for." When Brar discussed the need to keep the children safe, he discussed this in the context of the environment as a space. He seemed frustrated with this point, as he tried to articulate his philosophy of teaching, and how at times it is incompatible with regulations, and how this indicates that the environment is a "space we made. It's safe for them, it's not a place for them, it's safe." He spoke of how even inside, he steps in as children play to say, "ok, you have to be away from [a physical obstacle - i.e. a toy left on the footpath] because it's going to hurt you" and how this acts against his philosophy of, as he says, "making their mind strong. That's not going to make their mind strong because they are never seeing any hurdle." Here, he appeared frustrated with the ways in which the environment as a regulated space informed the power relations between himself and the children.

Similarly, there was some overlap between the findings relating to power in the classroom when conceptualized as space, and the role of regulations, and of power outside of the control of the educators. That is, Brar and Niki were more likely to consider their environment as a space when thinking about regulatory oversight: both theirs and the regulations that exist outside of their power. The educators described aspects of their daily routines and the space in which these aspects are carried out that 
are inscribed by the expectations of their organization, or of ministerial regulations - i.e., outdoor play, or sleep time. Niki suggested, "when we think about our classroom as a space, we think of limitations, we think of Ministry [of Education], we think of the rules... our codes, licensing, capacity... then we've got rules and regulations that we have to follow." I asked whose power is enacted when the room is considered a space. Niki was quick to answer with, "It's everybody else's power except for ours."

\section{The classroom as place.}

Both Niki and Brar indicate that they see their classroom as a place, and that their perceptions are that the children's interactions with the classroom are evidence of feeling a sense of place. During the interview Niki explained that her conceptualization of place is driven by a desire to create a "home away from home" within their classroom, a phrase she repeated when describing the children's comfort in their classroom and as her guiding principle for cultivating a sense of place. Niki's phrasing is purposeful when she described how she and Brar "interact along with them to gather more ideas and information we need" to plan. The phrasing indicates a communal effort to plan, contributing to Niki's sense of shared power within the classroom, and the classroom as one where its inhabitants experience a sense of place.

Yet, there appears to be a hesitancy to supplant the notion of space entirely, in a way that blurs the boundaries between space and place. Brar's thoughts on the environment as place seemed to shift depending on who was enacting power. During the interview, Brar suggested, for instance, "if you think from above [i.e., regulations], it's a space, if you think for yourself, as a classroom [and] what you're trying to do, it's a place." Here, he seemed to be suggesting that the classroom can be both a space and a place simultaneously, and that where power is situated is dependent upon whose perspective one takes. In this way, power, as Brar said, may come from above them, or alternately, the power in the classroom when they are alone with the children. Brar offered that, in their classroom, "we try to make a place for them, but still it's a space because we created it." In this statement, Brar's phrasing appears to situate the power in establishing a sense of place within his and Niki's efforts in the classroom.

In the final phase of data collection, Niki and Brar's reflective journals provided an interesting contrast in perception. Both Niki and Brar responded to a journal prompt that asked the participants to reflect on how they might re-think the environment in terms of space and place. 
Niki's reflection centred on the role of the educators, and while the children are mentioned, her perception appears to be one of what she and Brar can do to alter the environment to meet the needs and interests of the children. Conversely, Brar acknowledged that one way they might re-think their practice is by inviting the children to participate in the preparation of the environment and the materials. He indicated that by doing so, "they would feel freer and feel that it's their place... It will create a sense of belonging and well-being in the classroom." Here, Brar appears to accept the conceptualization of the environment as place, but concedes that despite the potential for sharing power, he feels a - real and perceived - obligation to the regulations imposed upon the learning environment. The power these regulations exert over the actions and experiences of the educators and children shape the encounters that take place in their room.

\section{Possibilities for Reconceptualizing Power, Space, and Place}

One challenge to reconceptualizing early childhood settings from space into place is the reticence on the part of early childhood educators to adopt shifting pedagogical stances, particularly ones that reflect a vision of shared power and shared meaning. Niki and Brar admit as much, indicating that discourses of accountability and regulatory practices flow downward and shape classroom practice. Place-based education may be one way to resituate power, as the place is not viewed as one for hierarchical, top-down learning, but one where knowledge and a sense of place are constructed and shared democratically (Brillante \& Mankiw 2015; Duhn 2012). Knowledge constructed under the auspices of space is, as Christensen (2003) suggests, not emplaced, but guided by adult perceptions of children as receptacles for knowledge, waiting to be filled by skilled educators. Power that produces inequities or hierarchies within spatialities requires critical reframing (Kernan 2010), and to do so reflects an ontological and epistemological commitment to educators and children sharing and enacting power, acting relationally in places with shared meaning.

One key conceptual argument to this paper is that power operates differently when early learning environments are viewed as places rather than spaces. Brillante and Mankiw (2015) write of a place-based approach to early learning environments and argue that children's power and agency is fostered in environments where they experience purposeful interactions between themselves, others, and the physical environment. The findings from this research suggest that while the participants 
articulated how power is situated between space and place, the ways in which techniques of power (Gore 1998) intersect may complicate and constrain how educators conceptualize their classroom in the context of space and place. Where are the openings for educators to contest and refuse hierarchical power in the pursuit of a place-based orientation to early childhood education? What might it mean to consider the complex ways in which techniques of power operate not as an inevitability, but instead as a possibility for reimagining philosophy and practice? Dovey (2010: 3) suggests that, "a large part of what distinguishes place from space is that place has an intensity that connects sociality to spatiality in everyday life." It would appear possible, then, to conceptualize early childhood settings as places that bridge the gap between social and spatial practices; however, Brar and Niki described the challenges in reframing their classroom as an issue of where power is situated and how it is enacted within the context of space and place.

Examining the way power in Niki and Brar's classroom is situated within a conceptualization of place is purposeful, because as Satta (2015: 182) explains, early learning environments are often "constructed following the adults' rather than the children's way of seeing things." When Niki and Brar described their perceptions of the differences between space and place, each acknowledged the conceptual, or philosophical difference, but ultimately, described how it is their power over the physical environment that governed decisions, such as environmental preparation, or in some cases, how and when the children encountered the environment. This has both ontological and epistemological implications, as Hackett (2016: 169) suggests, that, "movement through place creates embodied, tacit ways of knowing and experiencing the world," and that young children experience place as a site for learning and being within. This is not to suggest that children do not learn or experience a sense of being in place within Niki and Brar's classroom, but in early childhood contexts, power is situated much differently in environments where decisions concerning the physical environment are made for children, rather than with children. Here, I'll draw on one example from my observations of Niki and Brar's pedagogical movements to consider how pedagogy works to produce governable subjects in early childhood (Nxumalo, Vintimilla \& Nelson 2018; Smith 2012; 2014) and propose some questions as to how the situation might be imagined differently.

During the classroom observation phase of the research, Brar and Niki opted to stay indoors on a rainy day and move to the hallway of the school, just beyond their immediate classroom. Brar selected a bag of assorted balls for the children to play with in the hallways, and he and Niki positioned themselves at opposing ends of the long, narrow hallway as 
a physical manifestation of the boundaries within which children could play. Their bodies, in effect, were markers of the boundaries, a physical cue that announced and enforced the boundaries of the children's spatial range. When Niki and Brar describe their role as arbiters over children's safety and thus the spaces in which the children play, their governance inhibits the possibilities for children to share power within their experiences. Following this example, while the children were generally compliant with Niki and Brar's boundaries, it is possible to imagine a scenario where they are not compliant and actively resist. When Brar announced that it was time to leave the classroom to go play in the hall, selected the materials they would use, and he and Niki assumed their positions at the opposing ends of the hallway, these were decisions in which the children were not consulted. The children complied with their directions, but in an environment where power is reimagined within a more fluid pedagogical stance of shared or negotiated power, educators may encounter resistance with children asserting their power by refusing to accept the physical boundaries and negotiating an expansive understanding of the shared place. What pedagogical movements might have been made possible had the children and educators decided together on which materials they'd use, and in which place they'd be used? What might have been made possible if Niki and Brar were situated not at opposing ends, but together in the middle of the hallway? How might thinking pedagogically through a place-based orientation help refigure power relations between early childhood educators and young children? This is not to suggest a relativist pedagogy of anything goes, but that conceptualizing early childhood settings as place is one way in which educators and children think with one another, in ontological and epistemological stances where power is enacted in shared and negotiated ways.

Exploring how power is situated in early childhood settings within the context of place matters because, as Curtis (2015: 40) argues, a sense of place "is key to the development of a deep understanding of time in terms of both personal and collective ideas of history, being the context in which people experience it." When children and educators complicate traditional notions of power hierarchies and cultivate a sense of place together, it is an effort that affords each participant power over what is valued. When Niki and Brar described their perceptions of the classroom, and their relation to the concept of place, their descriptions were largely projections of how they feel in the classroom and how they feel the children perceive the classroom. Their perceptions and descriptions of practice were continually accompanied by the caveat that there are forces with power beyond their control - regulatory oversight, or organizational oversight, or time constraints - that limited their capacity to 
share or negotiate power with the children in cultivating a sense of place. Throughout the interview and their journals Niki and Brar indicated that their efforts are purposeful: they want children to feel comfortable, and there was no indication from the onsite observation that the opposite is true, but it is worth continually reflecting upon how the process of placemaking (Hackett et al. 2015) happens as a collaborative and negotiated practice.

The argument for rethinking early childhood spaces as early childhood places is of continual import in light of the findings within the context of the available scholarship, as researchers continue to situate the responsibility of cultivating a sense of place within the role of educators (Brillante \& Mankiw 2015). As place-based orientations for education (Duhn 2012; Strong-Wilson \& Ellis 2007; Taylor \& Giugni 2012) are developed further, it is necessary to ask who has power in determining what makes a space a place. In early childhood contexts that purport to be child-centred spaces or that honour children's capacity to share and enact power, it is presumptive when educators arrange and prepare the physical environment without the input of the children whose experiences are embodied within early childhood settings. The crux of the argument for reframing early childhood spaces as early childhood places is that doing so matters deeply for rethinking binaried pedagogical orientations. When children and educators cultivate a sense of place together, it is an effort that responds to the fluidity of who has power over what is valued. I argue, in light of the findings, that while early childhood educators may understand intuitively the demarcation between space and place, external constraints - both real and perceived - are a barrier to actionable change.

\section{Conclusion}

While binarized conceptions of child-led or teacher directed pedagogies pervade - both with their own assumptions about where power is located - some discourses in early childhood philosophy have shifted to reflect an ontological and epistemological stance that views children as competent and agentic participants in their learning. The theorizing and enactment of responsive pedagogies has followed suit, and early childhood educators have worked to develop and enact pedagogical practices that reconceptualize power relations in early childhood environments. However, despite the profound philosophical and pedagogical changes that early childhood educators have undertaken, it would seem that the pendulum-swing away from teacher-directed pedagogies toward child- 
centred pedagogies has not always materialized in equitable power dynamics. In some cases, the shift has resulted in the power imbalances being more explicitly observable due to the obvious contrasts between what is theorized and what is practiced. By avoiding binarized pedagogical stances, both children and educators are afforded time and space to share and negotiate power.

Power relations are further complicated by thinking of early childhood locales as geographical sites. The philosophical and geographical distinctions between space and place (Tuan 1977) are significant and are made more-so by interrogating where power is situated in both distinct conceptualizations. When I argue that power is more likely to be viewed as shared or negotiated when the environment is conceptualized as a place, it is precisely because the notion of 'felt value' that Tuan (1977) attributes to place, is, in social environments, a co-constructed feeling. Examining power relations through the lens of children's geographies and spatialities may be a valuable practice for educators who eschew hierarchical power relations between themselves and young children. Such reflections may prompt meaningful changes in the way environments are prepared and used, with power viewed as a negotiated or shared force resulting in more relational and entangled encounters with place.

In this research, while Niki and Brar provided thoughtful reflections on their own perceptions of power relations, the absence of children's participation in the research was a key limitation that points to directions for future research. The concept of power between early childhood educators and the intersections between power relations, space, and place, are significant, and require longer, more sustained research. Longerterm, ethnographic research into power relations across single or multiple sites would add further to ongoing conversations in reconceptualist early childhood theory and pedagogy.

Ultimately, the enactment of power is a negotiated act in early childhood settings. Power is rarely unidirectional, but often complicated by external factors. Educators act in accordance with the regulations and standards of their profession and their organizations, while the divide between what happens in practice and the discourses of children's power results in philosophical and pedagogical practices that exist within muddled ontological and epistemological stances. Early childhood educators can think with place as one possible way to reconceptualize early childhood environments to avoid obvious hierarchical power relations between themselves, young children, and the physical environment. Philosophies and pedagogies that reflect an understanding of early childhood locales as places with shared meaning can contribute to the cultivation of 
early childhood places where the enactment of power and the construction of knowledge is shared between educators and young children.

\section{REFERENCES}

Agnew, John. 2011. Place and space. In The SAGE Handbook of Geographical Knowledge, edited by J. Agnew and D. Livingstone. Los Angeles: SAGE.

Bloch, Marianne. 2013. Reconceptualizing theory/policy/curriculum/pedagogy in early child (care and) education: Reconceptualizing early childhood education (RECE) 1991-2012. International Journal of Equity and Innovation in Early Childhood 1 (1): 65-85.

Brillante, Pamela and Sue Mankiw. 2015. A sense of place: Human geography in the early childhood classroom. YC: Young Children 70 (3): 16-23.

Christensen, Pia. 2008. Place, space and knowledge: Children in the village and the city. In Transforming Learning in Schools and Communities: The Remaking of Education for a Cosmopolitan Society, edited by B. Lingard, J. Nixon and S. Ranson, 69-85. New York, NY: Continuum.

Christensen, Pia and Margaret O'Brien. 2003. Children in the City: Home, Neighbourhood and Community. London, UK: Routledge Falmer.

Crampton, Jeremy and Stuart Elden. 2007. Space, Knowledge and Power: Foucault and Geography. Aldershot, Hampshire, England: Ashgate.

Cresswell, Tim. 2004. Place: A Short Introduction. Malden, MA: Blackwell Pub.

Cresswell, Tim. 2008. Place: Encountering geography as philosophy. Geography 93 (3): 132-139.

Creswell, John and Cheryl Poth. 2017. Qualitative Inquiry and Research Design: Choosing Among Five Approaches (6th ed.). Thousand Oaks: Sage.

Critchley, Simon. 2001. Continental Philosophy: A Very Short Introduction. Oxford, UK: Oxford University Press.

Curtis, Elizabeth. 2015. The place of time in children's being. In Children's Spatialities: Embodiment, Emotion and Agency, edited by A. Hackett, L. Procter and J. Seymour, 39-50. Houndmills, Basingstoke Hampshire: Palgrave Macmillan.

Dahlberg, Gunilla, Peter Moss, and Alan Pence. 1999. Beyond Quality in Early Childhood: Education and Care. London, UK: Falmer Press.

de Certeau, Michael. 1986. Heterologies: Discourse on the Other. Manchester: Manchester University Press.

Dovey, Kim. 2010. Becoming Places: Urbanism/Architecture/Identity/Power. London \& New York: Routledge.

Duhn, Iris. 2012. Places for pedagogies, pedagogies for places. Contemporary Issues in Early Childhood 13 (2): 99-107. 
Elden, Stuart. 2001. Mapping the Present: Heidegger, Foucault and the Project of a Spatial History. London \& New York: Continuum.

Fenech, Marianne, Jennifer Sumsion, and Joy Goodfellow. (2008). Regulation and risk: Early childhood education and care services as sites where the 'laugh of Foucault' resounds. Journal of Education Policy 23 (1); 35-48.

Foucault, Michel. 1980. Power/Knowledge: Selected Interviews and Other Writings, 1972-1977. New York, NY: Pantheon Books.

Gandini, Lella. 1998. Educational and caring spaces. In The Hundred Languages of Children: The Reggio Emilia Approach-Advanced Reflections (2nd ed.), edited by C. Edwards, L. Gandini, and G. Forman, 161-178. Westport, CT: Ablex.

Gore, Jennifer. 1998. Disciplining bodies: On the continuity of power relations in pedagogy. In Foucault's Challenge: Discourse, Knowledge and Power in Education, edited by

T. Popkewitz, and M. Brennan, 231-251: New York: Teachers College Press.

Hackett, Abigail. 2016. Young children as wayfarers: Learning about place by moving through it. Children \& Society 30 (3): 169-179.

Hackett, Abigail, Lisa Procter, and Julie Seymour. 2015. Children's Spatialities: Embodiment, Emotion and Agency. Houndmills, Basingstoke Hampshire: Palgrave Macmillan.

Hamm, Catherine. 2015. Walking with place: Storying reconciliation pedagogies in early childhood education. Canadian Children 40 (2): 56-66.

Harrison, Steve and Paul Dourish. 1996. Re-place-ing space: The roles of place and space in collaborative systems. Proceedings of the 1996 ACM Conference on Computer Supported Cooperative Work, 67-76. Boston, MA.

Harrison, Andrew and Les Hutton. 2014. Design for the Changing Educational Landscape: Space, Place and the Future of Learning. London, UK: Routledge.

Hognestad, Karin and Marit Bøe. 2012. 'Place' as conceptual centre: A methodological focus on the bodily relations, movements and expressions of children up to three years of age in kindergarten. Reconceptualizing Educational Research Methodology 3 (2): 43-55.

Iannacci, Luigi and Pam Whitty. 2009. Early Childhood Curricula: Reconceptualist Perspectives. Calgary, AB: Detselig Enterprises.

Kernan, Margaret. 2010. Space and place as a source of belonging and participation in urban environments: considering the role of early childhood education and care settings. European Early Childhood Education Research Journal 18 (2): 199-213.

Kummen, Kathleen. 2010. Is it time to put "tidy up time" away?: Contesting routines and transitions in early childhood spaces. In Flows, Rhythms and Intensities of Early Childhood Education edited by Veronica PaciniKetchabaw, 97-112. New York: Peter Lang. 
Langford, Rachel. 2010. Critiquing child-centred pedagogy to bring children and early childhood educators into the centre of a democratic pedagogy. Contemporary Issues in Early Childhood 11 (1): 113-127.

Lenz Taguchi, Hillevi. 2010. Going Beyond the Theory/Practice Divide in Early Childhood Education: Introducing an Intra-active Pedagogy. New York, NY: Routledge.

MacNaughton, Glenda. 2005. Doing Foucault in Early Childhood Studies: Applying Poststructural Ideas. London: Routledge.

Massey, Doreen. 2005. For Space. London: SAGE Publications.

Merriam, Sharan. 2009. Qualitative Research: A Guide to Design and Implementation. San Francisco: Jossey-Bass.

Nairn, Karen and Peter Kraftl. 2016. Space, Place, and Environment: Geographies of Children and Young People. Singapore: Springer.

Nxumalo, Fikile, Cristina D. Vintimilla and Narda Nelson. 2018. Pedagogical gatherings in early childhood education: Mapping interferences in emergent curriculum. Curriculum Inquiry, 48 (4): 433-453.

Pacini-Ketchabaw, Veronica and Alan Pence. 2005. Contextualizing the reconceptualist movement in Canadian early childhood education. In Early Childhood Education in Motion: The Reconceptualist Movement in Canada edited by V. Pacini-Ketchabaw and A. Pence, 5-20. Ottawa: Canadian Child Care Federation.

Pacini-Ketchabaw, Veronica and Affrica Taylor. 2015. Unsettling the Colonial Places and Spaces of Early Childhood Education. New York: Routledge, Taylor \& Francis Group.

Philo, Chris. 1992. Foucault's geography. Environment and Planning D: Society and Space, 10 (2): 137-161.

Philo, Chris. 2010. Michel Foucault. In Key Thinkers on Space and Place, edited by P. Hubbard and R. Kitchin. London: SAGE Publications.

Raby, Rebecca. 2014. Children's participation as neo-liberal governance?. Discourse: Studies in the Cultural Politics of Education, 35 (1): 77-89.

Satta, Caterina. 2015. A proper place for a proper childhood? Children's spatialities in a play centre. In Children's Spatialities: Embodiment, Emotion and Agency, edited by A. Hackett, L. Procter and J. Seymour, 178-197. Houndmills, Basingstoke, Hampshire: Palgrave Macmillan.

Smith, Karen. 2012. Producing governable subjects: Images of childhood old and new. Childhood: A Global Journal of Child Research 19 (1): 24-37.

Smith, Karen. 2014. The government of childhood: discourse, power and subjectivity. Houndmills, Basingstoke, Hampshire: Palgrave Macmillan.

Stake, Robert. 2000. Case studies. In The Handbook of Qualitative Research, edited by N. K. Denzin and Y. S. Lincoln, 435-454. Thousand Oaks, CA: Sage. 
Strong-Wilson, Teresa and Julia Ellis. 2007. Children and place: Reggio Emilia's environment as third teacher. Theory into Practice 46 (1): 40-47.

Taylor, Affrica and Miriam Giugni. 2012. Common worlds: Reconceptualising inclusion in early childhood communities. Contemporary Issues in Early Childhood 13 (2): 108-119.

Tesar, Marek. 2014. Reconceptualising the child: Power and resistance within early childhood settings. Contemporary Issues in Early Childhood 15 (4): $360-367$.

Torquati, Julia and Julie Ernst. 2013. Beyond the walls: Conceptualizing natural environments as "Third educators". Journal of Early Childhood Teacher Education 34 (2): 191-208.

Tovey, Helen. 2007. Playing Outdoors: Spaces and Places, Risk and Challenge (Debating Play).

Buckingham: Open University Press.

Tuan, Yi-Fu. 1977. Space and Place: The Perspective of Experience. Minneapolis, MN: University of Minnesota Press.

Vuorisalo, Mari, Niina Rutanen, and Raija Raittila. 2015. Constructing relational space in early childhood education. Early Years 35 (1): 67-79.

Wood, Elizabeth Ann. 2014. Free choice and free play in early childhood education: Troubling the discourse. International Journal of Early Years Education 22 (1): 4-18.

Cory Jobb is an early childhood educator and a $\mathrm{PhD}$ student in Curriculum Studies at the University of Western Ontario. He is interested in thinking with pedagogies of place to explore how young children and educators make meaning of the tensions within landscapes that disrupt the nature/culture divide. His current research focuses on exploring pedagogies of place with young children and educators at a former municipal landfill-turned-public-space in Southern Ontario.

Email: cjobb@uwo.ca 